\title{
Design a Curriculum with User-Experience Analysis: Case Study Computing Science Curriculum
}

\author{
Punpiti Piamsa-nga ${ }^{1(\otimes)}$ and Yuen Poovarawan ${ }^{2}$ \\ ${ }^{1}$ Department of Computer Engineering, Kasetsart University, Bangkok, Thailand \\ pp@ku.ac.th \\ 2 Kasetsart University, Bangkok, Thailand \\ yuenaku.ac.th
}

\begin{abstract}
To improve the education, a new design of curriculum is always a part of the process. However, its development usually relies on the change of body of knowledge and class implementation. As a result, it might not succeed since it is compromised with issues in the deployment. In this paper, we propose to introduce a design concept on user experience (UX), which is extensively studied in the software engineering and computer science research, as a design tool. When the curriculum is improved, not only the body of knowledge is changed, the changes also affect all related resources and activities. If some of them was not well prepared, it would become the obstructions. The UX design/analysis is a process that uses meaningful experiences of all users in all aspects, such as resources, management, usability, and implementation. All related action roles to the system in the past is needed to be analyzed. The new curriculum should be designed based on possibility of implementation and optimized based on the user experience in the future. We introduce the study of computing science curriculum design for basic education. The case study has discussions on the analysis, the objective layout on the curriculum development, and the design of the curriculum.
\end{abstract}

Keywords: User experience $\cdot$ Computing science

\section{Introduction}

Thailand is currently facing serious issues and challenges in education. The OECD's Programme for International Student Assessment (PISA) shows that the country's school performance is lower than the OECD averages for all three subject areas: reading, mathematics and science [14]. Despite spending large budget on education [12], the results are unsatisfactory. The Independent Committee for Education Reform (ICER) has a set of mission reports on education reforms [6]. In these reports, identifying underlying problems based on the perspective of many that involved in the system has found the following major issues. First, students lack of critical skills; the traditional schooling is teacher-centered delivery contents to group of students, focusing on rote learning and 
memorization [3]. Second, teachers face many mandatory activities which are exhaustive but unproductive. For example, curriculum and program assessments require long man-hours of paperwork, but do not reflect real statues. Third, curriculum is usually seen as a core element for effective schooling, therefore it is often the object of reforms. However, the contents of each subject cannot be changed drastically. A small change without any new approach or new objective would not make any high impacts. Fourth, resource limitation is a main obstruction for speedy education reform on the large scale. At the national level, there are over 7.7 million of K-12 students, over 200 thousand of educational personnel, and over 10 thousand of schools, major change in curriculum would put pressure on revising teaching materials, teacher training and class management. Fifth, population decline in Thailand means that within 6 years, the number of active students will be reduced to 6.8 million. Seats in many universities will be vacant. In order to survive, universities need to reorganize their business model. The aforementioned problems indicate that a change is necessary but careful consideration should be given to both direct and indirect impacts when drawing new policies/curriculum. Otherwise the new policy may become obstructions to itself.

"Thailand becomes a developed country with security, prosperity and sustainability in accordance with the Sufficiency Economy Philosophy" is the vision as stipulated in the country's current 20-year National Strategy (2017-2036) [16]. The policy of Thailand 4.0 is a new economic model that aims to unlock the country from several economic challenges by moving the country into a new era defined by innovative technology-based manufacturing and services, changing traditional farming to smart farming, traditional SMEs to smart enterprises, traditional services to high-valued services, etc. [19]. To succeed, it requires "smart" citizens. People need to acquire new experiences, skills and knowledge [15]. To this end, the stagnant education system needs to reform to stay coherent with the evolving world.

\section{User Interfaces and User Experience}

When discussing on the design of software and system, user interface (UI) is a term that is more common and more recognizable. Users access and control the system to reach their objectives by the user interfaces. On the other hand, user experience (UX) is about how each user self-evaluates the system. UX design/analysis is a process to create knowledge models from relevant experiences on design, usability and function from all stakeholders in the system. It can help all users to understand the effects and impacts of the design before the system is implemented [5]. The experience is what users think and judge the system on their own way, not the necessary just on the user interfaces. Many good UI design failed because the users evaluated the system in other aspects. An example of good UI but fail UX is the case of tablet computer. Microsoft failed to deliver Tablet computer in 2000 but iPad succeeded in 2010 [16]. This shows that the success depended on the experience of the users.

Similarly, the curriculum usually is designed on the ideas to achieve goals of the curriculum designer. In this case, curriculum can be compared as the UI. The curriculum, in most case, means its body of knowledge and its contents, not how it is implemented. The case of UX in education is what people have learned on the education not only about 
the contents but also all related issues to implement the curriculum, such as resource management, personnel, outputs, outcomes, obstructions, risks, and opportunities. Many good curriculums failed by the related issues in the ecosystem of the education, which is not concerned or mentioned in the curriculum [1]. Mainly, the UX analysis are learned on each stakeholder. We believe that using the philosophy of the UX design should make the curriculum more feasibly successful.

\section{The Curriculum Design Issues}

Some issues of UX for the curriculum are listed as follows. These issues are further discussed in case study in the next section.

\section{Rapid Changes of Technology}

Body of knowledge of computing science is not rapidly changed but the technology is. However, the change of information technology affects the learning method. Students become digital native. They can access, manipulate or process the data and knowledge in different ways from the past. Digital contents are in different forms of media. All contents are connected via the Internet. Many of them are visualized multimedia contents, not just a textbook. The learning module becomes more virtualized into the cloud. It is not necessary that learning must be just in the classroom. It is also accessible in parallel. This is an issue that curriculum must fit the new learning method; otherwise, it may not be effective.

Therefore, technologies is not just platforms or tools to delivery knowledge or skills, but become a concept of implementation. Digital learning and active learning are examples of platforms that new curricula must base on.

\section{Focus on the Objectives}

Whether using any design tools or not, the philosophy and objectives of the curriculum are still the same. However, curriculum only define characteristics of knowledge of the student, but some important objectives may not be written explicitly [13]. For example, creative thinking is an objective that every student should have. However, there is no subject of "creative thinking" in the curriculum and it can only be taught through some activities in related classes. At the end, there would be no explicit emphasis about creative thinking in the curriculum at all.

To focus on the objectives, the content of curriculum itself must clearly reflect the objectives. In the example of creative thinking, it is a main objective in the curriculum that should be written in the class description. It should be written about how the students can learn to communicate efficiently, think creatively, solve problems systematically, using data and knowledge effectively, and understand new normal of knowledge society. This will make teachers understand the objectives rather than only acknowledge on the body of contents.

\section{The Goals Beyond the Curriculum Design}

The success of curriculum is not the success of education system. There are many issues beyond the curriculum design [11]. The extra issues related to the implementation of the 
curriculum such as availability and quality of teachers, class materials, class arrangement, and all side effects should be taken into consideration. These will become constraints in the curriculum deployment.

\title{
Implementation of the Curriculum
}

Not only design constraints should be concerned, but the implementation method is also needed to be designed carefully. Usually, implementation is based on availability and cost of current technology. Although the design constraints are obstruction, selecting appropriate implementation methods can make the system more possible. For example, while teaching in an era of Covid-19 virus outbreak is prohibited, the class may be continued using teleconference or broadcasting via the Internet. Most technology has its own cost and benefit. If the designer truly understands choices of implementation method, some obstacles could be avoid.

\begin{abstract}
All-Actors-Centered, Not Just Student-Centered
We must understand clearly, who the students are, who else are in the system, what the specialty of the curriculum is, how all people participate, how much all users are needed to change. By using the UX design, a user is not analyzed as an individual. A user role (actor), which is common behavior and common characteristics of a group of human users, is analyzed instead. User-experience of all actors are needed to be analyzed; then the analysis result is used to design a new UX.

Student is still the most important role in the education system, and it is the centered of the curriculum objective. However, as we know that the system can only continue when everybody from every role can survive in the system. At least, user experiences of student role and teacher role are needed to be analyzed. The UX design of students should make the curriculum succeeded and UX design of teacher should make the curriculum more feasible.
\end{abstract}

\section{Case Study: Computing Science for Basic Education}

In this section, we explain the design of the computing science in basic education in Thailand. We demonstrated the backgrounds and explained the design.

\subsection{Backgrounds}

The basic education curriculum is the national core curriculum which prescribed goals, learning standards and a framework for the development of primary and secondary school curriculum. It is formulated to support the national development plan. Thai government has recognized to important of computer education in today's society and has included Information and Communication Technology (ICT) as one of vocational subjects in basic education curriculum since 1990s [2].

Computer education became distinct subject and one of the mandatory subjects in Thai basic education curriculum in 2017 [7]. It was also given a new name to reflect the new teaching concept, which is about the science of computing applied on any subjects and applications, and it is now called computing science [7]. Technology is 
not the focal point since it changes too fast. The curriculum concentrates instead on the thinking method while programming is deployed as a learning tool. The objective is to develop students to be thinkers, developers, and entrepreneurs, as it has been mentioned in the national development plan. However, although the objective is about computing, the class still has major contents usually found in computer science. Some issues and challenges can be found in [17].

\subsection{The ICT Curriculum}

The inclusion of ICT in the basic education core curriculum in 1990s was the first time that computer education has been included in Thai curriculum. It was offered as a vocational subject and focused on general uses of computers, such as Office applications, to support subject and topic learning across the curriculum.

During the design process, the user experience analysis was not adopted. The curriculum design team was told to focus on the development of contents. The team consisted of professors from various universities and teachers from some selected schools. The professors knew all about contents of the subject, but they had never had any experiences in the field. On the other hand, the teachers knew the problem in the field, but they lacked understanding on effects of the curriculum changes.

Moreover, there was no available time slot on the students' class schedule. The effect of injecting the new content means some courses in the curriculum must be eliminated. Acquisition of equipment and its required environments, such as computer and internet, is also needed.

The curriculum was not widely successful due to lack of resources, qualified teachers, and interest of students. Computer resources were not widely available. There was no lab for computer exercises in many schools. Lessons were taught by non-specialist teachers since there was shortage of teachers with sufficient knowledge and training new ICT teachers took times. In some schools, the classes were successful at junior high school because the students understood the importance of the subject. However, it was much less interesting to senior high school students since their main focus were university entrance examination and ICT was not part it.

The UX Analysis. To understand the effects of the changes clearly, the UX analysis on all actors are proposed. In this case study, the actors are composed of science teachers, ICT teachers, school administrators, and students. All details are listed during the design process. Examples of UX design/analysis after the ICT course was adopted into the curriculum are shown in Table 1. It shows that user may think in the different way from the design and they always have alternatives. It is very possible that some resource conflicts may occur, and it would become obstruction to the implementation of the curriculum.

Other issues. Some extra lessons learned on the ICT curriculum design and implementation can be listed as follows.

- The design of curriculum was done in form of a committee. Their assignment was to consider only on the body of knowledge, which was usually not too different from any 
Table 1. Example of user experience and its effects.

\begin{tabular}{|c|c|c|}
\hline Actor roles & User experience & Effects from the user experience \\
\hline Student & $\begin{array}{l}\text { 1. New subject to learn } \\
\text { 2. New technology to adopt } \\
\text { 3. Another unimportant class since } \\
\text { it was not used for the university } \\
\text { entrance exam }\end{array}$ & $\begin{array}{l}\text { 1. More time to stay in class } \\
\text { 2. Possibly extra curriculum } \\
\text { needed to be reduced } \\
\text { 3. Students not interested to the } \\
\text { class }\end{array}$ \\
\hline Science teacher & $\begin{array}{l}\text { 1. Reduced workload because the } \\
\text { teaching hour is cut } \\
\text { 2. Increased workload because } \\
\text { there is no ICT teacher at school }\end{array}$ & $\begin{array}{l}\text { ICT curriculum is a threat to their } \\
\text { career }\end{array}$ \\
\hline ICT teacher & $\begin{array}{l}\text { 1. Good opportunity for career } \\
\text { 2. No schedule assigned because it } \\
\text { was filled by school } \\
\text { administrator } \\
\text { 3. They are not trained as ICT } \\
\text { teacher; need to be developed as } \\
\text { well } \\
\text { 4. More workload }\end{array}$ & $\begin{array}{l}\text { ICT curriculum is a threat if they } \\
\text { do not have backgrounds in } \\
\text { computer science }\end{array}$ \\
\hline School administrator & $\begin{array}{l}\text { 1. Need to develop science teacher, } \\
\text { or vocational teacher to be ICT } \\
\text { teacher } \\
\text { 2. Need to acquire computing } \\
\text { equipment } \\
\text { 3. Re-arranging class schedule and } \\
\text { teachers' workload }\end{array}$ & $\begin{array}{l}\text { 1. Lots of class and workload } \\
\text { management } \\
\text { 2. Acquiring and setting up } \\
\text { environment needs efforts and } \\
\text { time }\end{array}$ \\
\hline
\end{tabular}

other curricula in the same subject. Therefore, only the teaching and implementation guidelines, and some exercises were the main control from the conceptual design to the student as a final product.

- Body of knowledges in the curriculum was driven by the situation of the country and trends of available technology.

- The curriculum design was not integrated, and design was separated by subject. Students did not have an opportunity of real-world problems that needs collaborative solution from many subjects to solve it.

- The university entrance exam was a goal of student. The objective of the curriculum was irrelevant to them.

- Besides the class schedules, teachers still had lots of workload, such as class assessments from many organizations. Adding more tasks to teachers seem not to be a good attempt.

- The curriculum is more focus on the content that students should know rather than the life that the students should have. There are many extracurricular activities which students have to learn but are not part of the curriculum and therefore are not scheduled in regular school hours. 
- The limit that should be taken into consideration of the curriculum design: action roles of all users, studying hours of students, teaching hours of teachers, teaching resource management, and learning/studying materials.

\subsection{The Computing Science Curriculum}

The UX design. From the UX analysis of the ICT curriculum, the design issues are listed as follows.

The Philosophy, Objectives and Goals. The curriculum still reflects the philosophy, objectives and goals. In 2010s, the national development plan of Thailand is to promote knowledge economy. Innovative thinking is a key.

$U X$ of the Actors. When the curriculum contents are the main focus without taking the experiences, that the stakeholders will have, into consideration, the outcomes may not be as planned. Everyone always has a choice and it will be the best for him/her. For example, the basic programming is planned to deploy mainly in the junior high level, where it has been initially planned in the senior high level. However, by the UX analysis, students will not be interested in a class that was not a part of national university entrance exam. To avoid that situation, basic skill of computing science, such as Python programming, IoT concept, basic data collection and analysis, was mainly introduced at the junior high level. The class at the senior high level becomes like higher-education class, which has more advanced in software development, data analytics, and project. If some students elect not to continue with the subject at senior high, the curriculum is still successful with slight loss on less important topics.

The Education in the 21st Century. The idea of education in the $21^{\text {st }}$ century brings about the needs of student's characteristics, such as teamwork, leadership, globalization, work/living environment, ethics, design thinking, and engineering senses [8]. However, it was hard to include in the curriculum because the real-world problem requires combination of multiple disciplinaries to solve and the curriculum designer was told to focus only on the computer curriculum.

Focus on a Single Issue, then Expand it. Focus more than one point turns out to be out of focus. Everyone tries to maximize contents into time slots rather than focusing on the ultimate goals first and then extending what to do in details. For example, the focal point of curriculum at level 1 (primary level 1: grades 1-3) is defined as "unplugged". It means that students can solve real-life problems by algorithm without computers or devices. An example to represent outcomes is "student can describe directions from home to school with his/her reasons." It implies how to implement design thinking and critical thinking with the "unplugged" information technology into the curriculum. Focuses of other levels (grades 4-6, 7-9 and 10-12) are "daily life", "primary data", and "secondary data", respectively. Focus on a single issue with further expansion can make the goal of curriculum more understandable and more precise.

Explicitly Emphasis on Goals. A goal must be explicitly written in the curriculum; otherwise, it could not be effective. For example, if the goal is about the integration and 
problem solving, it is not possible to just talk about IT topics. Therefore, many ICTrelated social issues such as fake news and IT laws, are introduced in the computing science class. Previously, these topics were not included in the ICT class. They were more likely be placed in a social science class. However, it is now in the computing science curriculum because it will be more beneficial to build innovative and collaborative thinking to use ICT as parts of solution to the real-world problems than just pure ICT classes.

Design Based on Possible Resources. Resource availability is one of the most important issue to the success of curriculum deployment. The resources in this case includes class hours, teachers, course materials. Moreover, the resource conflict among users in the system should be avoided; otherwise, the curriculum would be rejected.

Curriculum. The curriculum has been deployed since 2007. The curriculum is activitybased, which is responded to the PISA. The activities in the curriculum emphasize on computational thinking and coding. Various platforms of software and IoT can be selected by schools.

The computing science curriculum is separated into 4 grade levels: level 1 primary education grades 1-3 (grades 1-3), level 2 primary education grades 4-6 (grades 4-6), level 3 secondary education grades 1-3 (grades 7-9) and level 4 secondary education grades 4-6 (grades 10-12).

The computing science curriculum has three underlying principles: computational thinking, ICT digital technology and digital, media and information literacy.

Computational Thinking. Acquired analytical, synthetic, constructive, critical and systematic thinking skills, leading to creation of bodies of knowledge or information for everyday life decision-making regarding oneself and society.

ICT Digital Technology. Acquired knowledge of current technologies and have ability to choose and apply them appropriately and ethically.

Digital, Media and Information Literacy. Ability to differentiate fake news and opinions from real news. Aware of cybersecurity and privacy issues.

Some extra design concepts from the above principles are listed as follows.

Technology Class. The computing science was not proposed as a science class, but the new section curriculum called "technology." To avoid name conflict of class with other science class, it is named only "computing." The concept of computing is about design thinking while using computer technology as a major tool.

Knowledge Integration. To use computing science as a thinking method to solve realworld problem is one of ultimate goals. Many tasks and activities in this class is designed from problems in other subjects. STEM concept is also used in the class implementation.

Extensible Design Concept. By the user experiences, the focus points of all four groups are "unplugged", "daily life", "primary data", and "secondary data". 
The unplugged was designed from perspective that the student is still very young, and the computing should be the understanding about themselves, thinking and reasoning on their daily life, and presenting or explaining in step by step.

The "daily life" was about how they use computer technology in their daily life, such as searching in the Internet, using online tools, making documents by office software. This group of students becomes familiar with computer technology. A huge number of students have own cell phones even though it is suggested that an under-13 student should not be online. However, dangers of being online has much higher risks. Teaching the risks and how to protect themselves online becomes an important issue in the curriculum.

The third group is the most important to the success of the curriculum. The "primary data" is designed for the junior high students to focus on how they generate primary data rather than what kind of technology they should learn or what programming language skill they should have. The knowledge society will become successful if the society have new knowledge to make new products or new services. Quality data would become quality knowledge. The body of knowledge includes the data processing issues, such as data sensors, data collection, IoT, basic programming, data privacy, copyright and patents, computer and data security, IT laws, etc.

The "secondary data" is designed for senior high student to use their knowledge and programming skills to further build real world application. Students was much less interested in this class since it was not a part of national entrance exam, the class is only appeal to some students who are seriously into computer science and its related technology. Therefore, any very important contents should not be included here. Advanced issues in computing such as AI and data science are also introduced. Datasets are not necessary built by themselves but acquired from others via computing technology. Students are expected to use computing skill and knowledge from other subjects to solve more complex problems from the secondary data sources.

Tools are Selective. Tools are not restricted. Teachers can use any kinds of technologies, programming languages, software packages, operating systems, PC, tablet devices, etc. For example, data collection can be done in paper or online questionnaires. PC is necessary only in a programming skill training class. Python programming language is recommended but not restricted. These are about avoiding problems of resource availability.

Technology Upgrade. Although computer science concept does not change much, the IT technology changes rapidly. New applications such as smart farm, Artificial Intelligence, Internet of Thing, online learning, collaborative tools become the main streams of attentions rather than the office software.

Curriculum Deployment. The curriculum has been deployed throughout the country in 2007. The overview of the curriculum is shown in Table 2. Success of curriculum is still too early to determine since it is still at an early stage of implementation. Obstructions from the resource availabilities, resource conflicts are negligible. The initialization of the deployment was comfortably successful. There were much less resistances. The total teaching hour in the class schedule was not changed. It is still the same as teaching time in the ICT curriculum. The number of teachers is still inadequate due to a graduate with skill in computing is likely to work on other jobs rather than teacher. 
Table 2. Example of user experience and its effects.

\begin{tabular}{|c|c|c|c|c|}
\hline Level & 1 & 2 & 3 & 4 \\
\hline Grades & $1-3$ & $4-6$ & $7-9$ & $10-12$ \\
\hline $\begin{array}{l}\text { Concept } \\
\text { keyword }\end{array}$ & Unplugged & Daily life & Primary Data & Secondary Data \\
\hline $\begin{array}{l}\text { Example of } \\
\text { skills }\end{array}$ & $\begin{array}{l}\text { Explain the } \\
\text { direction from } \\
\text { home to school } \\
\text { with reasoning }\end{array}$ & $\begin{array}{l}\text { Use computer and } \\
\text { the Internet to do } \\
\text { daily activities } \\
\text { such as searching } \\
\text { data and making } \\
\text { documents }\end{array}$ & $\begin{array}{l}\text { Collect data from } \\
\text { various tools such } \\
\text { as basic } \\
\text { questionnaire or } \\
\text { IoT and write a } \\
\text { program to do } \\
\text { basic control }\end{array}$ & $\begin{array}{l}\text { Use available data } \\
\text { to solve the } \\
\text { real-world } \\
\text { problem by } \\
\text { computer } \\
\text { programming }\end{array}$ \\
\hline $\begin{array}{l}\text { Computer } \\
\text { science } \\
\text { knowledge }\end{array}$ & $\begin{array}{l}\text { Basic problem } \\
\text { solving }\end{array}$ & $\begin{array}{l}\text { Use logic in } \\
\text { problem solving }\end{array}$ & $\begin{array}{l}\text { Use programing to } \\
\text { solve problems }\end{array}$ & \multirow{3}{*}{$\begin{array}{l}\text { Apply more } \\
\text { advanced } \\
\text { computing } \\
\text { technology with } \\
\text { knowledge from } \\
\text { other subjects to } \\
\text { solve real-world } \\
\text { problems }\end{array}$} \\
\hline ICT & $\begin{array}{l}\text { Skill to use basic } \\
\text { ICT tools }\end{array}$ & $\begin{array}{l}\text { Search data } \\
\text { sufficiently and } \\
\text { assess its } \\
\text { correctness }\end{array}$ & $\begin{array}{l}\text { Collect, analyze, } \\
\text { assess, present data } \\
\text { and information }\end{array}$ & \\
\hline $\begin{array}{l}\text { Digital } \\
\text { literacy }\end{array}$ & $\begin{array}{l}\text { Protect their } \\
\text { private data }\end{array}$ & $\begin{array}{l}\text { Understand rights } \\
\text { and } \\
\text { responsibilities on } \\
\text { data usage }\end{array}$ & $\begin{array}{l}\text { Use ICT with } \\
\text { responsibility and } \\
\text { understand basic } \\
\text { IT laws and ethics }\end{array}$ & \\
\hline $\begin{array}{l}\text { Example of } \\
\text { learning } \\
\text { platforms }\end{array}$ & $\begin{array}{l}\text { Unplugged } \\
\text { activities }\end{array}$ & $\begin{array}{l}\text { Basic office } \\
\text { software tools on } \\
\text { available } \\
\text { computer } \\
\text { platforms }\end{array}$ & $\begin{array}{l}\text { Designed lab with } \\
\text { various tools such } \\
\text { as KidBright }\end{array}$ & $\begin{array}{l}\text { Programming } \\
\text { with provided } \\
\text { data sources }\end{array}$ \\
\hline
\end{tabular}

Since the technology mentioned in the curriculum was not strictly selected, there are many choices for each technology. The class-material resources such computing equipment and software are also less required. Many learning platforms, such as CodingThailand.org [4] and KidBright [10], have been developed in conjunction with the curriculum deployment. Unplugged programming and Coding are very effective and requires much less resources. Young students pay more attention to the unplugged activities than those in the previous curriculum and teachers also do not need extra training [9]. Coding becomes trendy. It is easy for school to develop IoT or programming class since tools, devices and teaching material are much easier to access or acquire.

\section{Conclusions}

In this paper, we describe to use of user experience as a part of the curriculum design. User experience design and analysis is a process in computer science to develop software and 
system based on how the users think of when they use and how they react to the system. It brings about the understanding of projecting obstruction, which can be avoid before the implementation. In the case of curriculum, the users in this case are composed of students, teachers, and administrators. The issues in the analysis that must be taken into consideration are resource availability, resource conflict, and implementation method. The design of new curriculum must learn from the UX analysis of all stakeholders.

The case study demonstrates the development of computing curriculum in the basic education in Thailand. The ICT curriculum has been proposed to include as a science subject of basic education. The proposal was rejected, and it ended up being a vocational class. After analyzing on the user experience, the new curriculum design, namely "computing science", is successfully adopted as a core class in current basic education.

Acknowledgement. We would like to thank Nalina Phisanbut for her English reviews and comments.

\section{References}

1. Buasuwan, P.: Rethinking Thai higher education for Thailand 4.0. Asian Educ. Dev. Stud. 7(2), 157-173 (2018)

2. Bureau of academic affairs and educational standards. Basic Education Core Curriculum B.E. 2008 (Revised B.E. 2017) (2017)

3. Changwong, K., Sukkamart, A., Sisan, B.: Critical thinking skill development: analysis of a new learning management model for Thai high schools. J. Int. Stud. 11(2), 37-48 (2018)

4. CodingThailand. https://CodingThailand.org. Accessed 13 Apr 2020

5. Deitte, L.A., Omary, R.A.: The power of design thinking in medical education. Acad. Radiol. 26(10) (2019)

6. Independent Committee for Education Reform: Mission Reports (2019). https://www.thaied reform.org/knowledge/3127/. Accessed 13 Apr 2020

7. Institute for the promotion of teaching science and technology, Summary of the curriculum and comparison between the ICT curriculum and computing science curriculum (2018)

8. Jedaman, P., Buaraphan, K., Pimdee, P., Yuenyong, C., Sukkamart, A., Suksup, C.: Analysis of sustainable leadership for science learning management in the 21 st Century under education THAILAND 4.0 framework. In: AIP Conference Proceedings 1923, Article no. 030062 (2018)

9. Kanyacome, S., Poovarawan, Y.: The relationship between amusement and quality of learning by using gamification approach in creative youth camp. In: 2017 10th International Conference on Ubi-media Computing and Workshops (Ubi-Media), Pattaya, pp. 1-5 (2017)

10. Kid-bright. https://www.kid-bright.org/. Accessed 13 Apr 2020

11. Lee, J., Liu, A., Cheng, Y.C., Ma, S.-P., Lee, S.-J.: Execution plan for software engineering education in Taiwan. In: Proceedings - Asia-Pacific Software Engineering Conference, APSEC (2012)

12. Nitiwong, B.: Cost and pricing towards education industry and business in Thailand. In: The 5th Business, Economics and Communications International Conference (2015)

13. Piamsa-nga, P., Poovarawan, Y.: Engineering education from unlimited vision. In: The 36th Electrical Engineering Conference, Kanchanaburi, Thailand (2013)

14. Thailand Country Note, Programme for international student assessment (PISA) results from PISA (2018). https://www.oecd.org/pisa/publications/PISA2018_CN_THA.pdf. Accessed 13 Apr 2020 
15. Sethakul, P., Utakrit, N.: Challenges and future trends for Thai education: conceptual frameworks into action. Int. J. Eng. Pedagogy 9(2), 8-16 (2019)

16. Royal Thai government. National Strategies (2017-2036) In: Royal Thai Government Gazette, vol. 135, no. 82 (2018)

17. Webb, M., et al.: Computer science in the school curriculum: issues and challenges. In: Tatnall, A., Webb, M. (eds.) WCCE 2017. IAICT, vol. 515, pp. 421-431. Springer, Cham (2017). https://doi.org/10.1007/978-3-319-74310-3_43

18. Wetzlinger, W., Auinger, A., Dörflinger, M.: Comparing effectiveness, efficiency, ease of use, usability and user experience when using tablets and laptops. In: Marcus, A. (ed.) DUXU 2014. LNCS, vol. 8517, pp. 402-412. Springer, Cham (2014). https://doi.org/10.1007/978-3319-07668-3_39

19. Wongwuttiwat, J., Lawanna, A.: The digital Thailand strategy and the ASEAN community. Electron. J. Inf. Syst. Dev. Countries 84(3), Article no. e12024 (2018) 